\title{
Assessing the impacts of current and future concentrations of surface ozone on crop yield with meta-analysis
}

\author{
Zhaozhong Feng a,b, Kazuhiko Kobayashi a,* \\ ${ }^{a}$ Department of Global Agricultural Sciences, Graduate School of Agricultural and Life Sciences, The University of Tokyo, 1-1-1 Yayoi, Bunkyo-ku, Tokyo 113-8657, Japan \\ ${ }^{\mathrm{b}}$ State Key Laboratory of Urban and Regional Ecology, Research Center for Eco-Environmental Sciences, Chinese Academy of Sciences, Beijing 100085, PR China
}

\section{A R T I C L E I N F O}

\section{Article history:}

Received 11 September 2008

Received in revised form

25 November 2008

Accepted 26 November 2008

\section{Keywords:}

Ozone

Wheat

Rice

Soybean

Potato

Barley

Bean

\begin{abstract}
A B S T R A C T
Meta-analysis was conducted to quantitatively assess the effects of rising ozone concentrations $\left(\left[\mathrm{O}_{3}\right]\right)$ on yield and yield components of major food crops: potato, barley, wheat, rice, bean and soybean in 406 experimental observations. Yield loss of the crops under current and future $\left[\mathrm{O}_{3}\right]$ was expressed relative to the yield under base $\left[\mathrm{O}_{3}\right](\leq 26 \mathrm{ppb})$. With potato, current $\left[\mathrm{O}_{3}\right](31-50 \mathrm{ppb})$ reduced the yield by $5.3 \%$, and it reduced the yield of barley, wheat and rice by $8.9 \%, 9.7 \%$ and $17.5 \%$, respectively. In bean and soybean, the yield losses were $19.0 \%$ and $7.7 \%$, respectively. Compared with yield loss at current $\left[\mathrm{O}_{3}\right]$, future $\left[\mathrm{O}_{3}\right](51-75 \mathrm{ppb})$ drove a further $10 \%$ loss in yield of soybean, wheat and rice, and $20 \%$ loss in bean. Mass of individual grain, seed, or tuber was often the major cause of the yield loss at current and future $\left[\mathrm{O}_{3}\right]$, whereas other yield components also contributed to the yield loss in some cases. No significant difference was found between the responses in crops grown in pots and those in the ground for any yield parameters. The ameliorating effect of elevated $\left[\mathrm{CO}_{2}\right]$ was significant in the yields of wheat and potato, and the individual grain weight in wheat exposed to future $\left[\mathrm{O}_{3}\right]$. These findings confirm the rising $\left[\mathrm{O}_{3}\right]$ as a threat to food security for the growing global population in this century.
\end{abstract}

(c) 2008 Elsevier Ltd. All rights reserved.

\section{Introduction}

Ozone $\left(\mathrm{O}_{3}\right)$ is currently the most important air pollutant that negatively affects growth of both agricultural and native species in most parts of the world (Ashmore, 2005; Benton et al., 2000; Clarke et al., 1990; Fuhrer and Booker, 2003; Karnosky et al., 2007; Krupa et al., 2001; Wahid et al., 1995; Wang et al., 2007a). Limited measurements suggest that pre-industrial ground-level $\mathrm{O}_{3}$ concentration $\left(\left[\mathrm{O}_{3}\right]\right)$ was about $10 \mathrm{ppb}$ (Volz and Kley, 1988). The rapid economic growth during the second half of the last century has seen increased emission of $\mathrm{O}_{3}$ precursors, e.g. nitrogen oxides and volatile organic compounds, and the increase in surface $\left[\mathrm{O}_{3}\right]$ at an annual rate of $0.5-2 \%$ over the past decades (Vingarzan, 2004). The surface $\left[\mathrm{O}_{3}\right]$ has now reached a global mean of approximately $50 \mathrm{ppb}$ (8-h summer seasonal average) (Fiscus et al., 2005) exceeding the concentration against which the anthropogenic ozone impacts on plants are measured (Fuhrer et al., 1997). Ozone concentration in the Northern Hemisphere is projected to increase further by $20-25 \%$ between 2015 and 2050 , and by $40-60 \%$ by 2100 , if current emission trends continue (Meehl et al., 2007). Such levels of $\left[\mathrm{O}_{3}\right]$ could damage most crop species, and would largely reduce

\footnotetext{
* Corresponding author. Tel.: +81 35841 1292; fax: +81358415186.

E-mail address: aclasman@mail.ecc.u-tokyo.ac.jp (K. Kobayashi).
}

food production in the future. Indeed a conservative estimate of the crop losses to elevated $\left[\mathrm{O}_{3}\right]$ indicates an increase to $2-16 \%$ for wheat, rice and corn, and to $28-35 \%$ for soybeans in China, Japan and South Korea for 2020 (Wang and Mauzerall, 2004).

The increased crop losses to $\mathrm{O}_{3}$ will make it more difficult to meet the food demand of the global population, which is projected to increase from current ca. 6 billion to ca. 8 billion in 2025 (USBC, 2001), against the increasing risks of climatic changes and diminishing resources of land and fresh water (Gilland, 2002; Gregory and Ingram, 2000).

Numerous studies have shown that elevated $\left[\mathrm{O}_{3}\right]$ generally results in reduced photosynthesis and whole-plant growth, decreased stomatal conductance, altered antioxidant system, and accelerated senescence, although the extent of the effects varies by species or even cultivars (Ainsworth, 2008; Ashmore, 2005; Biswas et al., 2008; Clarke et al., 1990; Feng et al., 2006, 2007, 2008; Kobayashi et al., 1995; Long and Naidu, 2002; Morgan et al., 2003, 2006). Furthermore, elevated $\left[\mathrm{O}_{3}\right]$ can increase respiration rates and affect carbon allocation patterns, resulting in a decreased root: shoot ratio (Andersen, 2003; Biswas et al., 2008; Feng et al., 2006; Nouchi et al., 1995), or decreases in the leaf area ratio and specific leaf area (e.g. Morgan et al., 2003). Ozone can directly affect biochemical and/or physiological processes that might subsequently influence plant response to other biotic or abiotic stresses (e.g. Dixon et al., 1995; Fincher et al., 1989). 
Some research programs in the U.S. (National Crop Loss Assessment Network, NCLAN, see review by Heagle, 1989) and Europe (European Crop Loss Assessment Network, EUCLAN, review by Jäger et al., 1992) have derived relationships between "O ${ }_{3}$ dose" or " $\mathrm{O}_{3}$ exposure" and the yield of major crop species through controlled $\mathrm{O}_{3}$ fumigation experiments under near-field conditions using open-top chambers. Crop losses to $\mathrm{O}_{3}$ have been estimated with $\mathrm{O}_{3}$ monitoring data being input into the empirical $\mathrm{O}_{3}$ exposure-response functions. For example, the NCLAN program investigated 14 crop species across the U.S. in a total of 41 studies during a 7 -year period and indicated an approximate $5 \%$ yield loss and annual economy loss in excess of $\$ 1$ billion at the national level (Heagle, 1989; Murphy et al., 1999).

Outside North America and Europe also, significant effects of elevated $\left[\mathrm{O}_{3}\right]$ on crop yield have been estimated. In the Kanto region including the Tokyo Metropolitan area of Japan, yield loss in rice was estimated to range from $0 \%$ to $7 \%$ across the locations, and a $3 \%$ loss of rice production of the region was estimated on average across the 5 years from 1981 to 1985 (Kobayashi, 1992). The yield loss estimate was based on the relationship between the $\left[\mathrm{O}_{3}\right]$ and the crop growth derived from a 3-year study of ozone exposure of rice plants in field chambers (Kobayashi et al., 1995). In the Yangtze River Delta region of China, yield losses in 1999 due to $\mathrm{O}_{3}$ pollution were estimated to be $10.0 \%$ and $2.8 \%$ for wheat and rice, respectively (Feng et al., 2003), which was calculated from dose-response functions based on local open-top chamber studies and monitoring data in that region. Wang and Mauzerall (2004) estimated the $\mathrm{O}_{3}$ induced yield losses in major agricultural crops in China, Japan and South Korea for 1990 and 2020 using outputs of an air chemistrytransport model and the dose-response functions based on the NCLAN studies.

The dose-response functions have thus been quite useful in estimating the crop losses, but it must be noted that they represent only a portion of the large number of studies that have been conducted on the yield responses to ambient and elevated $\left[\mathrm{O}_{3}\right]$ with a variety of crops. These studies provide a large database from which it is feasible to obtain the mean response of crop yield to $\left[\mathrm{O}_{3}\right]$ by using meta-analysis. This approach has been used to examine soybean responses to elevated $\left[\mathrm{CO}_{2}\right]$ (Ainsworth et al., 2002) and elevated $\left[\mathrm{O}_{3}\right]$ (Morgan et al., 2003), wheat responses to elevated $\left[\mathrm{O}_{3}\right]$ (Feng et al., 2008), and rice responses to elevated $\left[\mathrm{CO}_{2}\right]$ and $\left[\mathrm{O}_{3}\right]$ (Ainsworth, 2008).

Here in this study, we use the meta-analysis as a means of quantitative estimate of the yield response to current and future $\left[\mathrm{O}_{3}\right]$ in major food crops. Our aims are to (1) summarize and synthesize the results of the numerous studies on the responses of yield and its components to current and future $\left[\mathrm{O}_{3}\right]$; and to (2) determine if different rooting environment and additional treatments, e.g. elevated $\left[\mathrm{CO}_{2}\right]$, significantly alter the responses of the crops to $\left[\mathrm{O}_{3}\right]$.

\section{Materials and methods}

\subsection{Database}

Relevant journal articles were searched for by a variety of keywords in the Web of Science (ISI) and by the list of references in reviews and meta-analyses. The search covered all peer-reviewed literature published on this topic between 1980 and 2007. To include an article in this meta-analysis, we examined if it met the following criteria: (1) the $\mathrm{O}_{3}$ fumigation period was longer than 10 days; (2) plant species were agricultural or horticultural crops; (3) $\left[\mathrm{O}_{3}\right]$ in the control treatment of the experiment was less than $26 \mathrm{ppb}$; (4) elevated $\left[\mathrm{O}_{3}\right]$ was in the range between 31 and $75 \mathrm{ppb}$ during exposure; and (5) measured responses included yield and its components such as individual grain, seed, or tuber weight, number of grains or seeds per unit harvested organ. The yields and individual grain, seed, or tuber mass were reported on dry weight basis except for potato, whose yield was sometimes, if not always, expressed on fresh weight basis.

We found studies with 17 crop species in total, but we report here the results with six major food crops: potato (Solanum tuberosum $\mathrm{L}$.), barley (Hordeum vulgare $\mathrm{L}$.), wheat (Triticum aestivum L.), rice (Oryza sativa L.), bean (Phaseolus vulgaris L.), and soybean (Glycine max (L.) Merr.). Appendix 1 lists the 81 publications used in this meta-analysis. The variables were considered independent if the data were obtained from separate experiments or from different treatments within a single experiment (e.g. different $\left[\mathrm{O}_{3}\right]$ treatments, years, species, cultivars, or additional treatments). There were 406 observations in total covered in this meta-analysis. Mean values for each variable were taken directly from tables or text, when reported. Data given only in the figures were digitized using GRAFULA software (Wesik SoftHaus, St. Petersburg, Russia).

To determine effects of ambient $\left[\mathrm{O}_{3}\right]$ on crop yield, we set the upper boundary of the base $\left[\mathrm{O}_{3}\right]$ level at $26 \mathrm{ppb}$, which was observed in charcoal-filtered (CF) air plots in some open-top chamber studies (e.g. Heck et al., 1988), and is very close to $25 \mathrm{ppb}$ that was used as the base $\left[\mathrm{O}_{3}\right]\left(\mathrm{B}-\mathrm{O}_{3}\right)$ in the NCLAN studies (Lesser et al., 1990). We then defined the current ambient 7 or $12 \mathrm{~h}$ daily $\left[\mathrm{O}_{3}\right]\left(\mathrm{C}-\mathrm{O}_{3}\right)$ as being in the range from 31 to $50 \mathrm{ppb}$. The low end of this range corresponds to the ambient atmospheric $\left[\mathrm{O}_{3}\right]$ at lesspolluted areas while the upper bound is close to current global daily mean $\left[\mathrm{O}_{3}\right]$ (Fiscus et al., 2005). The future ambient $\left[\mathrm{O}_{3}\right]\left(\mathrm{F}-\mathrm{O}_{3}\right)$ is assumed in the range from 51 to $75 \mathrm{ppb}$, based on the projections of Assessment Report Four (AR4) that $\left[\mathrm{O}_{3}\right]$ could further rise by $40-$ $60 \%$ by the year 2100 (Meehl et al., 2007). The boundaries are admittedly arbitrary, but are based on predictive studies with air chemistry-transport models (Meehl et al., 2007), whereas some projections suggest an even greater increase to $80 \mathrm{ppb}$ by 2100 (Fiscus et al., 2005). Indeed, $\left[\mathrm{O}_{3}\right]$ in some regions already exceeds the projections intermittently during the cropping season (Fiscus et al., 2005).

\subsection{Meta-analyses}

Each crop species was analyzed separately to obtain an estimate of the mean effect of elevated $\left[\mathrm{O}_{3}\right]$ on that species. The metaanalysis was conducted by using the MetaWin 2.0 statistical software (Rosenberg et al., 2000). To estimate the treatment effect, the natural $\log$ of the response ratio $\left(r=\right.$ value in elevated $\left[\mathrm{O}_{3}\right] /$ value in the base $\left[\mathrm{O}_{3}\right]$ ) was used as the metric for analysis (Hedges et al., 1999; Rosenberg et al., 2000) and reported as the percentage changes from $\mathrm{B}^{-} \mathrm{O}_{3}$ as $(r-1) \times 100 \%$ (Ainsworth et al., 2002; Curtis and Wang, 1998). Negative percentage changes indicate a decrease in the plant variable in response to elevated $\left[\mathrm{O}_{3}\right]$ treatment, whereas positive values indicate an increase.

Because many studies did not report information that would allow computation of sample variance (standard deviations or standard errors with replicate size), we had to use an un-weighted approach in which 95\% confidence intervals of the effect size were calculated by re-sampling the data using 9999 bootstrap replicates for each analysis (Adams et al., 1997). Estimates of the effect size were assumed to be significant if the 95\% confidence intervals did not overlap with zero (Curtis and Wang, 1998; Morgan et al., 2003).

To explain the variation in crop yields response to elevated $\left[\mathrm{O}_{3}\right]$, the data were divided into categories, such as different rooting environments ('pot' - rooted within a container, or 'ground' rooted directly in the earth), and additional treatments (drought, elevated $\left[\mathrm{CO}_{2}\right]$, and additional stress). Heterogeneity among levels of these categorical variables was assessed by re-sampling following Adams et al. (1997). For multiple comparisons, groups were considered to differ significantly if their 95\% confidence 
intervals did not overlap, providing a conservative test of group differences (Feng et al., 2008; Grantz et al., 2006; Morgan et al., 2003; Taub et al., 2008). Each categorical level for all crops was included in this analysis if there were at least two papers and five observations.

\section{Results}

\subsection{Current ambient $\left[\mathrm{O}_{3}\right]$ versus base $\left[\mathrm{O}_{3}\right]$}

All of the crops included in this analysis showed significant yield losses when grown at $\mathrm{C}_{-} \mathrm{O}_{3}$ relative to $\mathrm{B}-\mathrm{O}_{3}$ (Fig. 1). For potato, the mean yield loss was $5.3 \%$, whereas the yield losses for cereal crops: barley, wheat and rice, were $8.9 \%, 9.7 \%$ and $17.5 \%$, respectively. For the grain legumes: bean and soybean, the yield losses were $19.0 \%$ and $7.7 \%$, respectively. The average ambient $\left[\mathrm{O}_{3}\right]$ for all crops was within a range of $41-49 \mathrm{ppb}$. Among the six crops investigated, the largest yield loss was found in bean, with a mean response of $-19.0 \%(n=43)$ and a $95 \% \mathrm{CI}$ from $-12 \%$ to $-26 \%$ (Fig. 1$)$.

Response of the yield components to $\left[\mathrm{O}_{3}\right]$ varied with species (Fig. 2). In potato, $\mathrm{C}_{-} \mathrm{O}_{3}$ did not significantly decrease the individual tuber weight or tuber number per plant. In barley, $\mathrm{C}_{-} \mathrm{O}_{3}$ significantly reduced the individual grain weight (3.5\%) and ears per plant (4.8\%), but not number of grains per ear. In wheat, individual grain weight $(-6.2 \%)$ and number of grains per ear $(-5.9 \%)$ were both significantly decreased when exposed to a mean $\left[\mathrm{O}_{3}\right]$ of $39 \mathrm{ppb}$. In rice, the yield loss resulted from a combination of significant decreases in individual grain weight $(-3.1 \%)$, number of grains per panicle $(-8.4 \%)$ and panicles per plant $(-8.9 \%)$. In bean, $\mathrm{C}_{-} \mathrm{O}_{3}$ induced the yield loss as a result of significant decrease in individual seed weight $(-10.5 \%)$ and seeds per pod $(-12.3 \%)$, whereas only individual seed weight $(-5.1 \%)$ was significantly reduced by C$\mathrm{O}_{3}$ in soybean.

No significant difference was found for any variables between crops grown in pots and those grown in the ground (Table 1). In potato, soybean and wheat, the three species with the largest sample size, we categorized treatments into up to four different groups: no additional stress treatment, combination of $\mathrm{C}-\mathrm{O}_{3}$ with drought, combination of $\mathrm{C}-\mathrm{O}_{3}$ with elevated $\left[\mathrm{CO}_{2}\right]$, and combination of $\mathrm{C}_{-} \mathrm{O}_{3}$ with other stress treatments including low nitrogen, low or high temperature, low light, enhanced UV-B radiation, and elevated $\left[\mathrm{NH}_{3}\right]$ or $\left[\mathrm{NO}_{2}\right]$. Additional stress did not aggravate the $\mathrm{O}_{3}$-induced

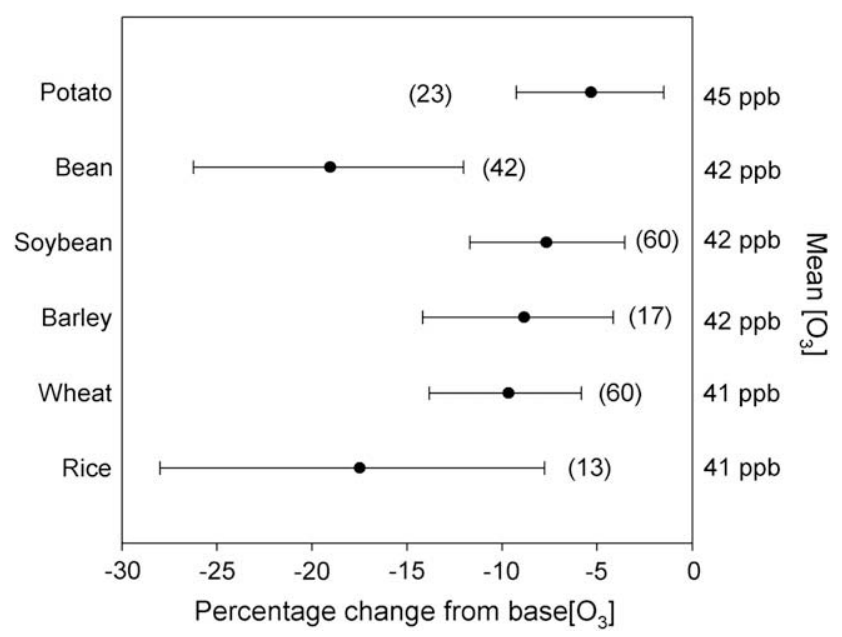

Fig. 1. Response of crop yields to current $\left[\mathrm{O}_{3}\right](31-50 \mathrm{ppb})$ for six crops. Symbols represent the mean percent change at current ambient $\left[\mathrm{O}_{3}\right]$ relative to base $\left[\mathrm{O}_{3}\right]$ $(\leq 26 \mathrm{ppb}$ ) and the bars show the $95 \%$ confidence intervals (CIs). Degree of freedom (d.f.) for each species is given in parenthesis. Mean $\left[\mathrm{O}_{3}\right]$ is expressed on $\mathrm{y}$-axis.

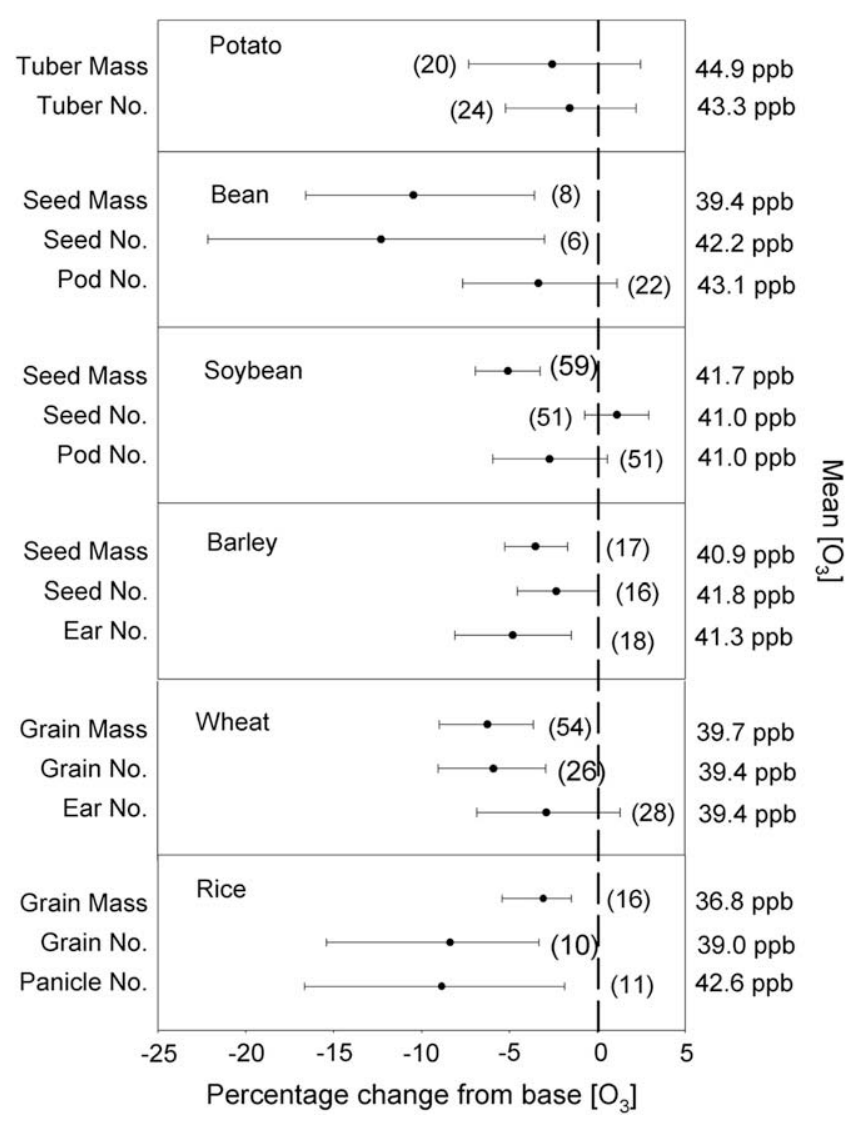

Fig. 2. Response of yield components to current ambient $\left[\mathrm{O}_{3}\right](31-50 \mathrm{ppb})$ for six crops. See Fig. 1 for explanation of the notations.

negative effects on any variables. To the contrary, elevated $\left[\mathrm{CO}_{2}\right]$ ameliorated the detrimental effects of $\mathrm{C}-\mathrm{O}_{3}$ relative to those under ambient $\left[\mathrm{CO}_{2}\right]$, although significant difference was found only in individual grain mass of wheat (Fig. 3).

\subsection{Future $\left[\mathrm{O}_{3}\right]$ versus base $\left[\mathrm{O}_{3}\right]$}

As noted before, $\mathrm{F}-\mathrm{O}_{3}$ was assumed to range from 51 to $75 \mathrm{ppb}$. Our results demonstrated that $\mathrm{F}_{-} \mathrm{O}_{3}$ of $63 \mathrm{ppb}$ significantly decreased yield by $41.4 \%, 21.6 \%$ and $21.1 \%$ in bean, soybean and wheat, respectively, relative to $\mathrm{B}^{-\mathrm{O}_{3}}$ (Fig. 4). The largest loss was observed in bean with the mean response being $41.4 \%$ and its $95 \% \mathrm{CI}$ of $27.7-52.7 \%$, which was significantly greater than all other crops but rice (Fig. 4). There were no significant differences among barley, wheat, rice, or soybean with respect to the yield response to $\mathrm{F}-\mathrm{O}_{3}$. Consistent with the results with current ambient $\left[\mathrm{O}_{3}\right]$, potato yield loss at $\mathrm{F}_{-} \mathrm{O}_{3}$ was the smallest (11.9\%).

Responses of the yield components to $\mathrm{F}_{-} \mathrm{O}_{3}$ (Fig. 5) differed from those to $\mathrm{C}-\mathrm{O}_{3}$ (Fig. 2). In potato, $\mathrm{O}_{3}$-induced reduction in individual tuber weight $(7.2 \%)$ contributed to the yield loss more than tuber number per plant (4.4\%) (Fig. 5). In barley, $\mathrm{F}_{-} \mathrm{O}_{3}$ significantly reduced individual grain weight (3.6\%) and number of ears per plant (10.7\%). Yield loss (21\%) in wheat resulted from a combination of decreased individual grain weight (12.9\%), fewer ears per plant $(6.35 \%)$ and less grains per ear (6.8\%). In rice, $\mathrm{F}_{-} \mathrm{O}_{3}$ significantly reduced individual grain weight $(4.0 \%)$ and grains per panicle (5.8\%), but did not affect number of panicles per plant. In legumes, the yield losses in bean (41.4\%) and soybean (21.6\%) resulted from reduced individual seed weight $(25.6 \%$ for bean and $14.0 \%$ for soybean) and fewer pods per plant (20.5\% for bean and $11.1 \%$ for soybean) (Fig. 5). 
Table 1

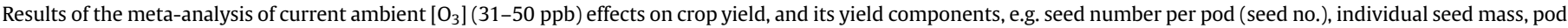
number per plant (pod no.) under different rooting environments.

\begin{tabular}{|c|c|c|c|c|c|c|c|}
\hline \multirow[t]{2}{*}{ Crop } & \multirow[t]{2}{*}{ Variable } & \multirow[t]{2}{*}{ Rooting Environment } & \multirow[t]{2}{*}{ d.f. } & \multirow[t]{2}{*}{$\%$ Change from base $\left[\mathrm{O}_{3}\right]$} & \multicolumn{2}{|l|}{$95 \% \mathrm{CI}$} & \multirow[t]{2}{*}{ Mean $\left[\mathrm{O}_{3}\right](\mathrm{ppb})$} \\
\hline & & & & & Minimum & Maximum & \\
\hline Potato & Tuber Yield & $\begin{array}{l}\text { Pot } \\
\text { Ground }\end{array}$ & $\begin{array}{r}7 \\
15\end{array}$ & $\begin{array}{l}-6.46 \\
-3.01\end{array}$ & $\begin{array}{c}-11.5 \\
-8.06\end{array}$ & $\begin{array}{r}-1.41 \\
2.06\end{array}$ & $\begin{array}{l}44 \\
45\end{array}$ \\
\hline Bean & $\begin{array}{l}\text { Seed Yield } \\
\text { Pod No. }\end{array}$ & $\begin{array}{l}\text { Pot } \\
\text { Ground } \\
\text { Pot } \\
\text { Ground }\end{array}$ & $\begin{array}{r}32 \\
9 \\
14 \\
7\end{array}$ & $\begin{array}{r}-19.2 \\
-18.5 \\
-5.77 \\
1.33\end{array}$ & $\begin{array}{c}-27.7 \\
-28.0 \\
-10.5 \\
-6.93\end{array}$ & $\begin{array}{c}-10.4 \\
-6.69 \\
-1.16 \\
9.90\end{array}$ & $\begin{array}{l}42 \\
43 \\
44 \\
41\end{array}$ \\
\hline Soybean & $\begin{array}{l}\text { Seed Yield } \\
\text { Seed Mass } \\
\text { Seed No. } \\
\text { Pod No. }\end{array}$ & $\begin{array}{l}\text { Pot } \\
\text { Ground } \\
\text { Pot } \\
\text { Ground } \\
\text { Pot } \\
\text { Ground } \\
\text { Pot } \\
\text { Ground }\end{array}$ & $\begin{array}{l}38 \\
21 \\
38 \\
20 \\
38 \\
12 \\
38 \\
12\end{array}$ & $\begin{array}{r}-6.73 \\
-9.31 \\
-6.30 \\
-2.79 \\
1.33 \\
0.45 \\
-1.20 \\
-7.11\end{array}$ & $\begin{array}{c}-11.8 \\
-15.6 \\
-8.78 \\
-5.08 \\
-0.55 \\
-3.93 \\
-4.76 \\
-13.3\end{array}$ & $\begin{array}{r}-1.12 \\
-3.09 \\
-3.78 \\
-0.30 \\
3.27 \\
5.02 \\
2.48 \\
-0.92\end{array}$ & $\begin{array}{l}42 \\
41 \\
42 \\
40 \\
42 \\
37 \\
42 \\
37\end{array}$ \\
\hline Barley & $\begin{array}{l}\text { Grain Yield } \\
\text { Grain Mass } \\
\text { Ear No. }\end{array}$ & $\begin{array}{l}\text { Pot } \\
\text { Ground } \\
\text { Pot } \\
\text { Ground } \\
\text { Pot } \\
\text { Ground }\end{array}$ & $\begin{array}{l}8 \\
8 \\
7 \\
9 \\
8 \\
9\end{array}$ & $\begin{array}{c}-10.9 \\
-6.72 \\
-3.45 \\
-3.60 \\
-6.70 \\
-3.09\end{array}$ & $\begin{array}{c}-19.9 \\
-11.4 \\
-6.53 \\
-5.36 \\
-11.73 \\
-7.04\end{array}$ & $\begin{array}{r}-3.46 \\
-1.85 \\
0.04 \\
-1.79 \\
-2.11 \\
1.53\end{array}$ & $\begin{array}{l}46 \\
38 \\
45 \\
37 \\
46 \\
37\end{array}$ \\
\hline Wheat & $\begin{array}{l}\text { Grain Yield } \\
\text { Grain Mass } \\
\text { Grain No. } \\
\text { Ear No. }\end{array}$ & $\begin{array}{l}\text { Pot } \\
\text { Ground } \\
\text { Pot } \\
\text { Ground } \\
\text { Pot } \\
\text { Ground } \\
\text { Pot } \\
\text { Ground }\end{array}$ & $\begin{array}{r}24 \\
35 \\
20 \\
33 \\
9 \\
16 \\
19 \\
8\end{array}$ & $\begin{array}{l}-9.34 \\
-9.90 \\
-2.98 \\
-8.18 \\
-7.54 \\
-4.93 \\
-3.52 \\
-1.52\end{array}$ & $\begin{array}{c}-14.5 \\
-15.9 \\
-7.27 \\
-11.5 \\
-11.4 \\
-9.38 \\
-7.42 \\
-11.2\end{array}$ & $\begin{array}{r}-4.16 \\
-4.52 \\
1.17 \\
-5.09 \\
-3.63 \\
-0.89 \\
0.23 \\
9.37\end{array}$ & $\begin{array}{l}42 \\
39 \\
41 \\
39 \\
44 \\
37 \\
41 \\
35\end{array}$ \\
\hline Rice & Grain Mass & $\begin{array}{l}\text { Pot } \\
\text { Ground }\end{array}$ & $\begin{array}{r}10 \\
5\end{array}$ & $\begin{array}{l}-2.14 \\
-4.8\end{array}$ & $\begin{array}{c}-3.36 \\
-10.4\end{array}$ & $\begin{array}{l}-1.09 \\
-1.24\end{array}$ & $\begin{array}{l}35 \\
40\end{array}$ \\
\hline
\end{tabular}

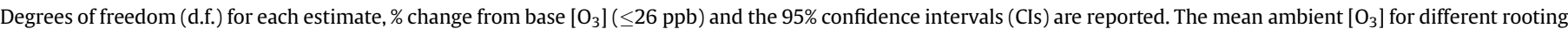
environment is also reported.

Comparing all studies performed in pots with those involving plants rooted in the ground, no variables showed a significant difference in any crops (Table 2). There were some indications that elevated $\left[\mathrm{CO}_{2}\right]$ or drought ameliorated the detrimental effects of $\mathrm{F}$ $\mathrm{O}_{3}$ on the yield and its components (Fig. 6). However, only the yield of wheat and potato, and individual grain weight of wheat showed significantly smaller response to $\mathrm{F}-\mathrm{O}_{3}$ under elevated $\left[\mathrm{CO}_{2}\right]$, compared with that in ambient $\left[\mathrm{CO}_{2}\right]$. Surprisingly, the other stress treatments including low nitrogen and low light did not significantly alter the $\mathrm{O}_{3}$ response for any variables in any crops species included (Fig. 6).

\section{Discussion}

\subsection{Are current ambient levels of $\mathrm{O}_{3}$ causing yield loss in major food crops?}

This meta-analysis indicated that surface $\left[\mathrm{O}_{3}\right]$ at the current ambient-level induced an average yield loss of $11.3 \%$ in the range from $5 \%$ to $19 \%$ in the six major food crops including cereals, grain legumes and tubers. The results are compared with those reported in previous quantitative reviews. Morgan et al. (2003) indicated a mean yield loss in soybean of about $10 \%$ exposed to $30-60 \mathrm{ppb}$ $\left[\mathrm{O}_{3}\right]$, which is comparable to the $7.7 \%$ decrease seen in this study relative to the width of the confidence intervals.

With wheat, our previous meta-analysis found the mean yield loss of $17.5 \%$ and the range from $11.2 \%$ to $24.0 \%$ in response to mean $\left[\mathrm{O}_{3}\right]$ of $43 \mathrm{ppb}$ with a range of $30-59 \mathrm{ppb}$ (Feng et al., 2008), whereas we found only $9.7 \%$ (5.8-13.8\%) yield loss in this study. The difference between this and the previous studies can be mostly attributed to the difference in the reference $\left[\mathrm{O}_{3}\right]$. Our main concern in this paper is the impacts of current and future $\left[\mathrm{O}_{3}\right]$ on crops. The base $\left[\mathrm{O}_{3}\right]$ was hence defined as being less than $26 \mathrm{ppb}$, which is very close to the base $\left[\mathrm{O}_{3}\right]$ in the NCLAN studies (Lesser et al., 1990) as mentioned earlier. The base $\left[\mathrm{O}_{3}\right]$ in this study included both charcoal-filtered and non-filtered $\left[\mathrm{O}_{3}\right]$ below $26 \mathrm{ppb}$, and hence it ranged from 3 to $25 \mathrm{ppb}$ with the mean across studies being $13.8 \mathrm{ppb}$. In the previous study (Feng et al., 2008), on the other hand, we focused on the contrast between control and elevated $\left[\mathrm{O}_{3}\right]$, and hence setting the reference $\left[\mathrm{O}_{3}\right]$ equal to the charcoalfiltered $\left[\mathrm{O}_{3}\right]$, which was on average $6 \mathrm{ppb}$ and ranged from 3 to $10 \mathrm{ppb}$. The lower reference $\left[\mathrm{O}_{3}\right]$ in the previous study should have contributed to the larger effect of $\left[\mathrm{O}_{3}\right]$ than the present study. Inclusion of the observations under elevated $\left[\mathrm{CO}_{2}\right]$ into this study has only slightly reduced the effects of elevated $\left[\mathrm{O}_{3}\right]$ as compared with the previous one, which evaluated the effect of elevated $\left[\mathrm{CO}_{2}\right]$ separately. Without $\left[\mathrm{CO}_{2}\right]$ enrichment, the wheat yield loss ranged from $6 \%$ to $16 \%$ with mean yield loss being $11 \%$ (Fig. 3 ), which is only slightly greater than the yield loss including the elevated $\left[\mathrm{CO}_{2}\right]$ treatment.

Most studies indicated that rice was less sensitive to chronic $\mathrm{O}_{3}$ exposure than other major food crops (Feng et al., 2003; Kobayashi et al., 1995; Mills et al., 2007; Wang et al., 2007b). Nevertheless, this analysis demonstrated that the yield loss in rice was as high as $17.5 \%$ at mean $\left[\mathrm{O}_{3}\right]$ of $41 \mathrm{ppb}$. This is primarily because of the results with the Pakistani varieties: IRRI-6 and Basmati 385, which showed a yield reduction of $36-57 \%$ when exposed to the mean $\left[\mathrm{O}_{3}\right]$ of $40-$ $44 \mathrm{ppb}$ (Maggs et al., 1995; Maggs and Ashmore, 1998). Noting the 


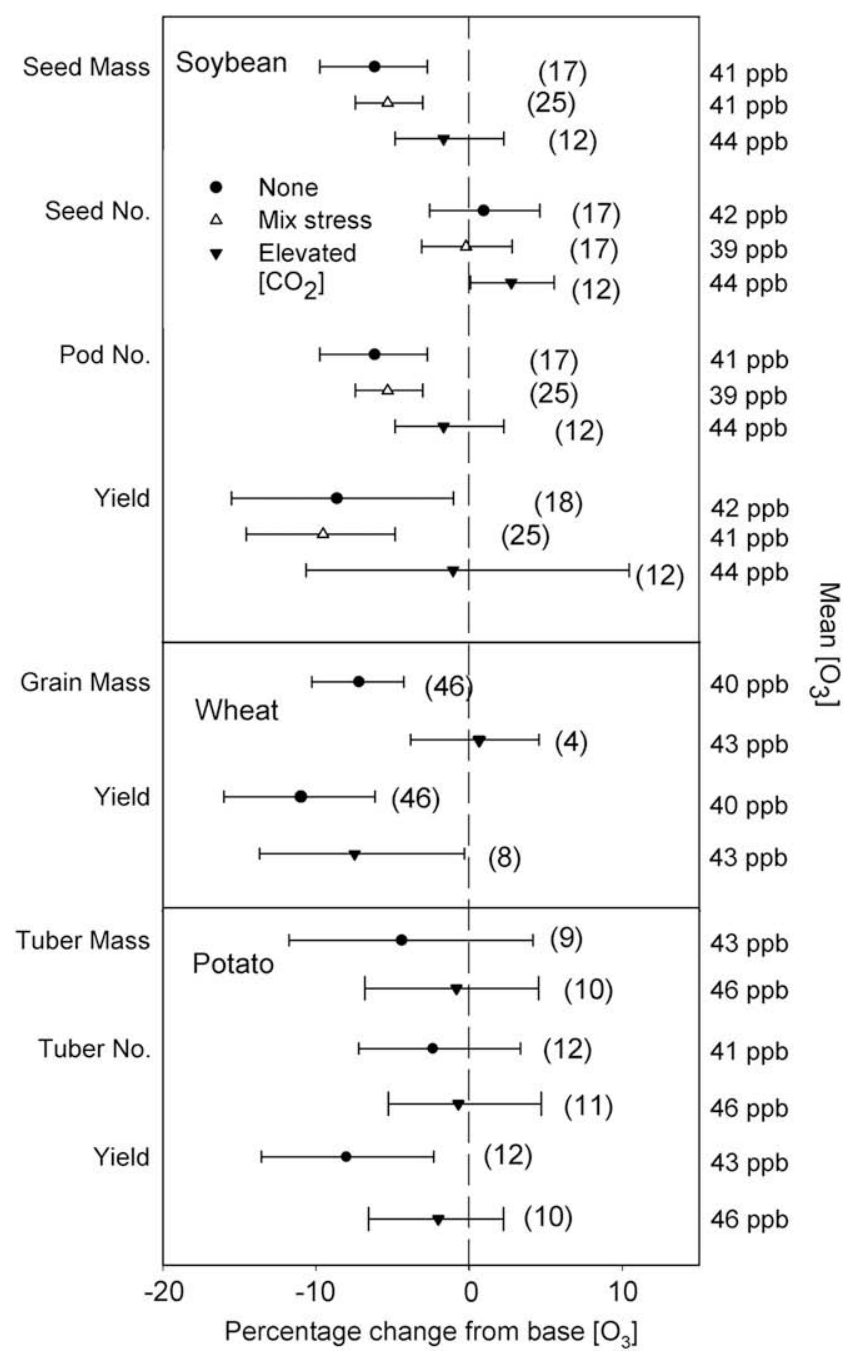

Fig. 3. Responses of crop yield and yield components to current ambient $\left[\mathrm{O}_{3}\right]$ (31$50 \mathrm{ppb}$ ) in combination with additional treatments. See Fig. 1 for explanation of the notations.

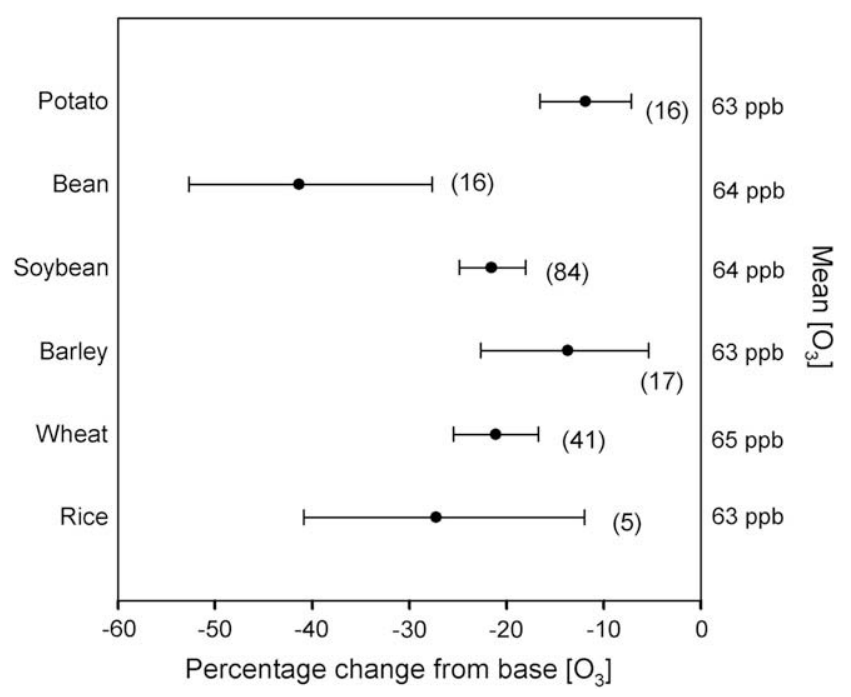

Fig. 4. Response of crop yields to future ambient $\left[\mathrm{O}_{3}\right](51-75 \mathrm{ppb})$ for six crops. See Fig. 1 for explanation of the notations.

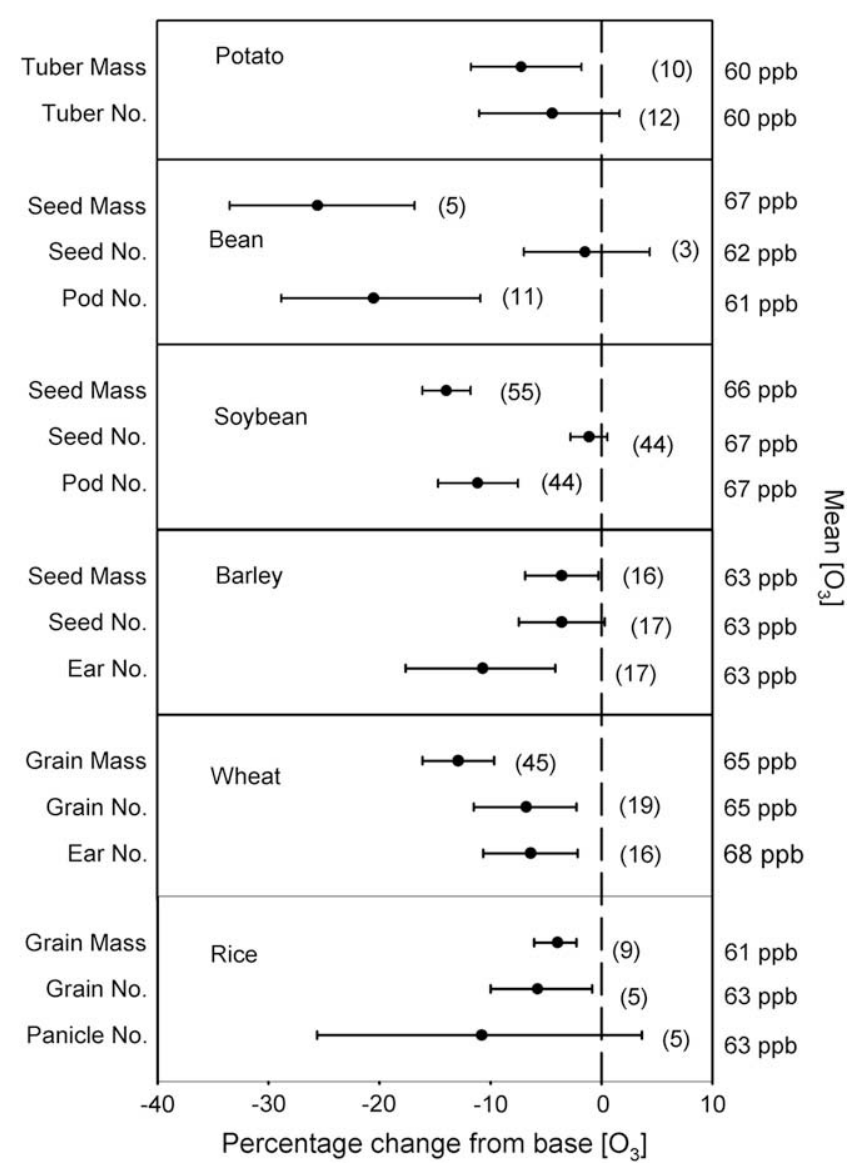

Fig. 5. Response of yield components to future $\left[\mathrm{O}_{3}\right](51-75 \mathrm{ppb})$ for six crops. See Fig. 1 for explanation of the notations.

anomalously low harvest index, e.g. 0.16 in the filtered-air treatment, in those studies (Maggs et al., 1995; Maggs and Ashmore, 1998), we reanalyzed the data excluding them. The results showed that current $\left[\mathrm{O}_{3}\right]$ reduced yield in rice by $7.4 \%$, with a $95 \% \mathrm{CI}$ of $5.75-$ $9.33 \%$, which is smaller than that found initially (Fig. 1), and is comparable to other species. It is thus suggested that rice is no less sensitive to current ambient $\left[\mathrm{O}_{3}\right]$ than other species. Similar results with rice have also been reported by Ainsworth (2008).

In the Yangtze River Delta of China, surface $\left[\mathrm{O}_{3}\right]$ measurements demonstrated that mean $\left[\mathrm{O}_{3}\right]$ across the rice growing season (JulyOctober) ranged from 38 to $46 \mathrm{ppb}$ and the average across the locations was $43 \mathrm{ppb}$ (Wang et al., 2006), which is higher than the mean current ambient $\left[\mathrm{O}_{3}\right](41 \mathrm{ppb})$ in this meta-analysis. Therefore, it can be inferred that $\mathrm{O}_{3}$ has already been reducing rice production in China, where the farmers produce approximately one-third of the global rice crop (Coats, 2003).

The largest yield loss in our results was $19 \%$ with bean, along with a $95 \%$ CI of $12-26 \%$, which is based on 43 measurements and 13 individual studies, 22 cultivars and/or lines and across seven countries under $\left[\mathrm{O}_{3}\right]$ in the range of $30-50 \mathrm{ppb}$. This result indicated that bean is very sensitive to $\mathrm{O}_{3}$, in agreement with the study of Mills et al. (2007), who ranked bean as the most sensitive among agricultural crops according to $\mathrm{O}_{3}$ critical levels (AOT40 for $5 \%$ yield reduction). Filtration studies at Mediterranean sites, where $\mathrm{O}_{3}$ exposures are among the highest in Europe, have shown yield loss above $20 \%$ of $P$. vulgaris L. (Schenone et al., 1992).

Fresh or processed potato tubers already form a major component of the human diet and may become increasingly important for human nutrition, especially in developing countries, because the ratio of edible to non-edible components (harvest index) is much 
Table 2

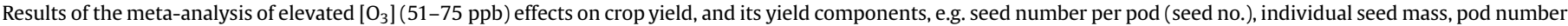
per plant (pod no.) under different rooting environments.

\begin{tabular}{|c|c|c|c|c|c|c|c|}
\hline \multirow[t]{2}{*}{ Crop } & \multirow[t]{2}{*}{ Variable } & \multirow[t]{2}{*}{ Rooting Environment } & \multirow[t]{2}{*}{ d.f. } & \multirow[t]{2}{*}{$\%$ Change from base $\left[\mathrm{O}_{3}\right]$} & \multicolumn{2}{|l|}{$95 \% \mathrm{CI}$} & \multirow[t]{2}{*}{ Mean elevated $\left[\mathrm{O}_{3}\right](\mathrm{ppb})$} \\
\hline & & & & & Minimum & Maximum & \\
\hline Bean & Seed Yield & $\begin{array}{l}\text { Pot } \\
\text { Ground }\end{array}$ & $\begin{array}{r}11 \\
4\end{array}$ & $\begin{array}{l}-41.4 \\
-41.2\end{array}$ & $\begin{array}{l}-51.8 \\
-65.6\end{array}$ & $\begin{array}{r}-28.1 \\
0.39\end{array}$ & $\begin{array}{l}63 \\
68\end{array}$ \\
\hline Soybean & $\begin{array}{l}\text { Seed Yield } \\
\text { Seed Mass } \\
\text { Seed No. } \\
\text { Pod No. }\end{array}$ & $\begin{array}{l}\text { Pot } \\
\text { Ground } \\
\text { Pot } \\
\text { Ground } \\
\text { Pot } \\
\text { Ground } \\
\text { Pot } \\
\text { Ground }\end{array}$ & $\begin{array}{l}33 \\
50 \\
28 \\
26 \\
27 \\
16 \\
27 \\
16\end{array}$ & $\begin{array}{c}-24.6 \\
-19.5 \\
-16.4 \\
-11.3 \\
-0.81 \\
-1.60 \\
-11.0 \\
-11.4\end{array}$ & $\begin{array}{c}-30.2 \\
-23.2 \\
-19.7 \\
-13.5 \\
-3.16 \\
-3.68 \\
-15.7 \\
-15.7\end{array}$ & $\begin{array}{r}-18.3 \\
-15.5 \\
-12.9 \\
-9.04 \\
1.53 \\
0.82 \\
-5.76 \\
-6.44\end{array}$ & $\begin{array}{l}66 \\
63 \\
67 \\
65 \\
67 \\
66 \\
67 \\
66\end{array}$ \\
\hline Wheat & $\begin{array}{l}\text { Grain Yield } \\
\text { Grain Mass }\end{array}$ & $\begin{array}{l}\text { Pot } \\
\text { Ground } \\
\text { Pot } \\
\text { Ground }\end{array}$ & $\begin{array}{l}15 \\
25 \\
16 \\
28\end{array}$ & $\begin{array}{l}-20.0 \\
-21.8 \\
-10.1 \\
-14.5\end{array}$ & $\begin{array}{l}-26.4 \\
-27.4 \\
-13.9 \\
-19.0\end{array}$ & $\begin{array}{c}-14.1 \\
-15.9 \\
-6.08 \\
-9.99\end{array}$ & $\begin{array}{l}65 \\
65 \\
68 \\
63\end{array}$ \\
\hline
\end{tabular}

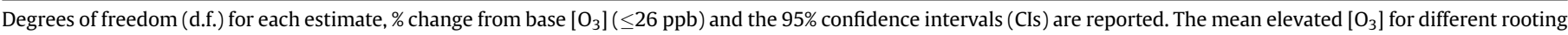
environment is also reported.

greater than in cereals such as wheat, rice and maize (Vandermeiren et al., 2005). CHIP was a large-scale OTC project to provide field-based data spanning a wide range of climatic conditions and $\mathrm{O}_{3}$ concentrations in Europe using a common cultivar, Bintje (De Temmerman et al., 2002). Our results supported the model simulations based on the CHIP dataset, and indicated that elevated $\left[\mathrm{O}_{3}\right]$ would reduce potato tuber yield by $3-5 \%$ across Europe (Wolf and Van Oijen, 2003).

The exposure-response relationships have allowed the yield losses for different crops to be estimated for a given ozone exposure (Ashmore, 2002). According to the linear dose-response model (Mills et al., 2000, 2007), we estimated the yield loss of individual crop, and compared with the results of this meta-analysis (Table 3 ). Among the crop species, rice, bean and soybean exhibited responses to elevated $\left[\mathrm{O}_{3}\right]$ comparable between the two methods. For wheat, the mean yield loss from dose-response function was greater than that from this meta-analysis. This is possibly because this study included observations conducted in greenhouses and controlled growth chambers as well as those in open-top chambers, whereas the dose-response functions were derived from open-top chamber experiments (Mills et al., 2000, 2007). It has been found that the effects of ozone on wheat growth tend to be less in indoor growth chambers than in open-top chambers (Feng et al., 2008).

A larger difference was found between the two approaches in potato yield response to $\left[\mathrm{O}_{3}\right]$ (Table 3 ). Our results showed lower yield loss possibly due to the observations under elevated $\left[\mathrm{CO}_{2}\right]$. Fig. 3 shows that the $\mathrm{O}_{3}$-induced yield loss in potato is less when combined with elevated $\left[\mathrm{CO}_{2}\right](-2 \%)$ than in ambient $\left[\mathrm{CO}_{2}\right](-8 \%)$, and that the yield loss in ambient $\left[\mathrm{CO}_{2}\right]$ has the $\mathrm{CI}$ that overlaps with the yield loss estimate from the exposure-response relationship. For barley, the yield loss estimated from Mills et al. (2000, 2007) studies is based on a very weak correlation $\left(r^{2}=0.0012\right.$, $n=47$ ) between the relative yield and the ozone dose, and, hence, should be subject to a large estimation error. The apparent difference between the two approaches for barley (Table 3) should therefore be considered non-significant.

Numerous studies have shown that $\mathrm{O}_{3}$ frequently reduces yield in grain crops by decreasing ear and pod numbers, seed numbers per ear, spikelet or pod (and hence seed number per plant), and individual seed weight (see review by Black et al., 2000). From our meta-analysis, response of different yield components to $\left[\mathrm{O}_{3}\right]$ varied by crop species and treatment $\left[\mathrm{O}_{3}\right]$. It is noteworthy that reduced weight of individual grain or seed is often the major cause of the yield loss to $\mathrm{O}_{3}$ in cereals and grain legumes (Figs. 2 and 5). This yield component is under genetic control, and usually most conservative among the yield components against the environmental stresses. It is affected by occurrence of stresses only during the grain filling stage. The results in Figs. 2 and 5 hence imply that the effect of ozone on crop yield is exerted through accumulation of the damages or that the plants are more sensitive to ozone at the later stages.

\subsection{To what extent will future levels of surface $\mathrm{O}_{3}$ reduce yield of major food crops?}

In this meta-analysis, we assumed that future $\left[\mathrm{O}_{3}\right]$ is represented by a daytime concentration of 51-75 ppb during the crop growth. The average daytime $\left[\mathrm{O}_{3}\right]$ in the studies reviewed in this analysis increased from $42 \mathrm{ppb}$ for current ambient air to $63 \mathrm{ppb}$ for future air. Given the current emission trends, surface $\left[\mathrm{O}_{3}\right]$ is projected to rise globally by 20-25\% between 2015 and 2050, and $40-60 \%$ by 2100 (Meehl et al., 2007), supporting our assumptions on current and future $\left[\mathrm{O}_{3}\right]$. Compared with yield loss at current ambient $\left[\mathrm{O}_{3}\right]$, future $\left[\mathrm{O}_{3}\right]$ could drive a further $10 \%$ decrease in yield for soybean, wheat and rice, and $20 \%$ for bean, indicating the future

Table 3

Comparison of yield losses estimated from this meta-analysis and dose-response function, based on average $\left[\mathrm{O}_{3}\right]$ of all observations for specific crop species.

\begin{tabular}{|c|c|c|c|c|c|c|}
\hline & Potato & Barley & Wheat & Rice & Bean & Soybean \\
\hline$\overline{\left[\mathrm{O}_{3}\right](\mathrm{ppb})^{\mathrm{a}}}$ & 44.7 & 41.9 & 40.5 & 41 & 42.3 & 41.8 \\
\hline Yield loss $(\%)^{\mathrm{b}}$ & 12.1 & 3.87 & 14.4 & 8.95 & 17.9 & 9.13 \\
\hline Yield loss $(\%)^{c}$ & $1.5-9.24$ & $4.15-14.2$ & $5.83-13.8$ & $5.75-9.33^{d}$ & $12-26.2$ & $3.53-11.7$ \\
\hline
\end{tabular}

${ }^{a}$ Average $\left[\mathrm{O}_{3}\right]$ from all observations for specific crop species.

b Estimated from exposure-response function (Mills et al., 2000, 2007).

c Calculated from this meta-analysis.

d The data were estimated excluding the studies of Maggs et al. (1995), due to lower HI. 


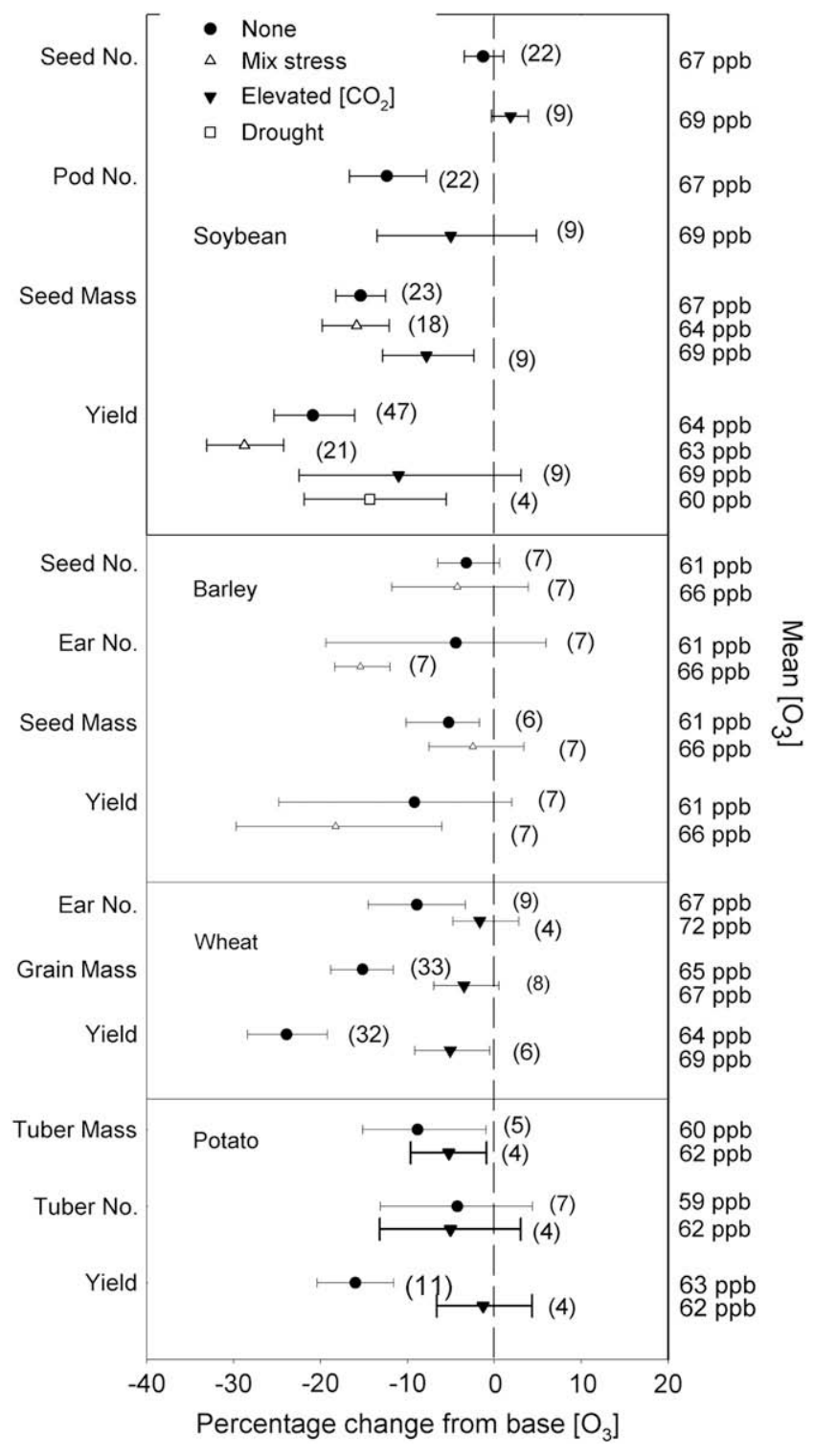

Fig. 6. Responses of crop yield and yield components to future $\left[\mathrm{O}_{3}\right](51-75 \mathrm{ppb})$ in combination with additional treatments. See Fig. 1 for explanation of the notations.

$\left[\mathrm{O}_{3}\right]$ as a significant threat against food production in the world (Ashmore et al., 2006).

It must be noted that $\mathrm{O}_{3}$ is not the only element of global change, and that $\mathrm{O}_{3}$ will interact with other factors such as water stress, $\left[\mathrm{CO}_{2}\right]$ and temperature. Previous meta-analyses showed that elevated $\left[\mathrm{CO}_{2}\right]$ and drought significantly lessen the yield loss due to elevated $\left[\mathrm{O}_{3}\right]$ in soybean (Morgan et al., 2003) and wheat (Feng et al., 2008). In this study also, elevated $\left[\mathrm{CO}_{2}\right]$ ameliorated the detrimental effects of elevated $\left[\mathrm{O}_{3}\right]$ (Fig. 6). The interacting effects of elevated $\left[\mathrm{CO}_{2}\right]$ are very important when predicting the $\mathrm{O}_{3}$ impacts on crop production under higher $\left[\mathrm{CO}_{2}\right]$ in the future (Fiscus et al., 2005). The elevated $\left[\mathrm{CO}_{2}\right]$ will reduce stomatal conductance and, thereby, $\mathrm{O}_{3}$ uptake into leaves. The $\mathrm{O}_{3}$ impacts will be less than those predicted from $\left[\mathrm{O}_{3}\right]$ under current $\left[\mathrm{CO}_{2}\right]$ (Fiscus et al., 2005), because of the reduced $\mathrm{O}_{3}$ uptake in combination with other changes due to elevated $\left[\mathrm{CO}_{2}\right]$ (Booker and Fiscus, 2005; CardosoVilhena et al., 2004). Other factors than $\left[\mathrm{CO}_{2}\right]$ could also change in the future, and alter the impacts of increasing $\left[\mathrm{O}_{3}\right]$. In this study, however, they did not change the $\mathrm{O}_{3}$ impact significantly (Fig. 6), possibly because of the smaller number of observations for the interactive effects than the previous studies (Feng et al., 2008; Morgan et al., 2003).

To address the interacting effects of elevated $\left[\mathrm{CO}_{2}\right]$ and other factors on the $\mathrm{O}_{3}$ impacts, the flux-based dose-response relationships (Pleijel et al., 2007) would be better suited than the concentration-based approach (Pleijel et al., 2004). This is clearly a step forward toward the mechanism-based estimation of the crop losses. However, the estimation of $\mathrm{O}_{3}$ uptake requires extra pieces of information for stomatal conductance, and therefore the flux-based approach is currently limited to wheat and potato, for which the relevant data are available across a number of studies (Pleijel et al., 2007). The same limitation applies to the meta-analysis to an even greater extent. If the $\mathrm{O}_{3}$ dose were to be flux-based rather than concentration-based, the meta-analysis would lose its virtue of being based on all available publications, most of which lacks the information to estimate the $\mathrm{O}_{3}$ uptake. As a more feasible approach in meta-analysis, the observations were grouped according to additional treatments, some of which alter the $\mathrm{O}_{3}$ uptake, and the $\mathrm{O}_{3}$ impacts were compared between the groups. The ameliorating effects of elevated $\left[\mathrm{CO}_{2}\right]$ due largely to reduced $\mathrm{O}_{3}$ uptake (Fiscus et al., 2005) have been confirmed in this and other meta-analyses (Feng et al., 2008; Morgan et al., 2003).

The distinction between $\left[\mathrm{O}_{3}\right]$ and $\mathrm{O}_{3}$ uptake also raises a concern about the alteration to the $\mathrm{O}_{3}$ impacts by chambers. It has been shown that, in open-top chambers, $\mathrm{O}_{3}$ uptake by plants is either larger (Nussbaum and Fuhrer, 2000) or smaller (Piikki et al., 2008) than in the field to the extent that would alter the resultant impacts on plants. Free-air controlled environment (FACE) technology provides a means to examine the impact of elevated $\left[\mathrm{O}_{3}\right]$ relative to current background $\left[\mathrm{O}_{3}\right]$ without the alterations to $\mathrm{O}_{3}$ uptake by chambers (McLeod and Long, 1999). Using a FACE system, Morgan et al. (2006) showed that a $23 \%$ increase in $\left[\mathrm{O}_{3}\right]$ from an average daytime ambient level of $56 \mathrm{ppb}$ to the elevated level of $69 \mathrm{ppb}$ over two growing seasons caused a $20 \%$ decrease in soybean yield. This is much larger than the $8 \%$ yield loss expected from the chamber results. It must therefore be noted that the detrimental effects of elevated $\left[\mathrm{O}_{3}\right]$ may be larger than those estimated in this study as well as other studies based on the exposure-response functions derived from chamber experiments. FACE experiments are urgently needed for major crop species to better predict the impacts of increasing surface $\left[\mathrm{O}_{3}\right]$. It is of particular importance to study rice under elevated $\left[\mathrm{O}_{3}\right]$ and $\left[\mathrm{CO}_{2}\right]$, for which studies are lacking even in chambers (Ainsworth, 2008). Rice is the most important staple crop in Asia, where we could see a large increase in surface $\left[\mathrm{O}_{3}\right]$ in the near future (Wang and Mauzerall, 2004; Yamaji et al., 2008). As we found in this study, rice is no less sensitive to elevated $\left[\mathrm{O}_{3}\right]$ than other species.

\section{Acknowledgments}

We acknowledge Drs. Elizabeth A. Ainsworth and Jindong Sun of University of Illinois at Urbana-Champaign for their helpful comments in the initial draft. We also appreciate an anonymous reviewer for the critical comments on the initial manuscript of this paper. This study was supported by Eco-Frontier Fellowship (07C062-03), the Global Environment Research Fund (C-062) by the Ministry of Environment, Japan, and Special Project for Environmental Protection Sector, China (200809152).

\section{Appendix. References used in meta-analysis of current and future ozone effects}

Soybean

Booker, F.L., Miller, J.E., Fiscus, E.L., Pursley, W.A., Stefanski, L.A., 2005. Comparative responses of container- versus ground-grown soybean to elevated carbon dioxide and ozone. Crop Science 45, 883-895. 
Chernikova, T., Robinson, J.M., Lee, E.H., Mulchi, C.L., 2000. Ozone tolerance and antioxidant enzyme activity in soybean cultivars. Photosynthesis Research 64, 15-26.

Cure, W.W., Nusser, S.M., Heagle, A.S., 1988. Canopy reflectance of soybean as affected by chronic doses of ozone in open-top field chambers. Photogrammetric Engineering and Remote Sensing 54, 499-504.

Fiscus, E.L., Reid, C.D., Miller, J.E., Heagle, A.S., 1997. Elevated $\mathrm{CO}_{2}$ reduces $\mathrm{O}_{3}$ flux and $\mathrm{O}_{3}$-induced yield losses in soybeans: possible implications for elevated $\mathrm{CO}_{2}$ studies. Journal of Experimental Botany 48, 307-313.

Heagle, A.S., Flagler, R.B., Patterson, R.P., Lesser, V.M., Shafer, S.R., Heck, W.W. 1987. Injury and yield response of soybean to chronic doses of ozone and soil moisture deficit. Crop Science 27, 1016-1024.

Heagle, A.S., Miller, J.E., Pursley, W.A., 1998. Influence of ozone stress on soybean responses to carbon dioxide enrichment: III. Yield and seed quality. Crop Science $38,128-134$

Heggestad, H.E., Anderson, E.L., Gish, T.J., Lee, E.H., 1988. Effects of ozone and soil water deficit on roots and shoots of field-grown soybeans. Environmental Pollution 50, 259-278.

Heggestad, H.E., Lee, E.H., 1990. Soybean root distribution, top growth and yield responses to ambient ozone and soil moisture stress when grown in soil columns in greenhouses. Environmental Pollution 65, 195-207.

Heggestad, H.E., Lesser, V.M., 1990. Effects of ozone, sulfur dioxide, soil water deficit and cultivar on yields of soybean. Journal of Environmental Quality 19, 488-495.

Jones, H.C., Noggle, J.C., McDuffie, C., 1988. Effects of chronic exposure to simulated power plant emissions and ozone in soybean production. Journal of Environmental Quality 17, 701-707.

Kohut, R.J., Amundson, R.G., Laurence, J.A., 1986. Evaluation of growth and yield of soybean exposed to ozone in the field. Environmental Pollution (Series A) 41, 219-234.

Kress, L.W., Miller, J.E., 1983. Impact of ozone on soybean yield. Journal of Environmental Quality 12, 276-281.

Kress, L.W., Miller, J.E., Smith, H.J., Rawlings, J.O., 1986. Impact of ozone and sulphur dioxide on soybean yield. Environmental Pollution (Series A) 41,105-123. Miller, J.E., Booker, F.L., Fiscus, E.L., Heagle, A.S., Pursley, W.A., Vozzo, S.F., Heck, W.W., 1994. Ultraviolet-B radiation and ozone effects on growth, yield, and photosynthesis of soybean. Journal of Environmental Quality 23, 83-91.

Miller, J.E., Heagle, A.S., Vozzo, S.F., Philbeck, R.B., Heck, W.W., 1989. Effects of ozone and water stress, separately and in combination on soybean yield. Journal of Environmental Quality 18, 330-336.

Mulchi, C.L., Lee, E.H., Tuthill, K., Olinick, E.V., 1988. Influence of ozone stress on growth processes, yields and grain quality characteristics among soybean cultivars. Environmental Pollution 53, 151-169.

Mulchi, C.L., Slaughter, L., Saleem, M., Lee, E.H., Pausch, R., Rowland, R., 1992 Growth and physiological characteristics of soybean in open-top chambers in response to ozone and increased atmospheric $\mathrm{CO}_{2}$. Agriculture, Ecosystems and Environment 38, 107-118.

Robinson, J.M., Britz, S.J., 2000. Tolerance of a field grown soybean cultivar to elevated ozone level is concurrent with higher leaflet ascorbic acid level, higher ascorbate-dehydroascorbate redox status, and long term photosynthetic productivity. Photosynthesis Research 64, 77-87.

Troiano, J., Colavito, L., Heller, L., McCune, D.C., Jacobson, JS., 1983. Effects of acidity of simulated rain and its joint action with ambient ozone on measures of biomass and yield in soybean. Environmental and Experimental Botany 23, 113-119.

Barley

Adaros, G., Weigel, H.J., Jäger, H.-J., 1991. Concurrent exposure to $\mathrm{SO}_{2}$ and/or $\mathrm{NO}_{2}$ alters growth and yield responses of wheat and barley to low concentrations of $\mathrm{O}_{3}$. New Phytologist 118, 581-591.

Adaros, G., Weigel, H.J., Jäger, H.-J., 1991. Growth and yield of spring rape and spring barley as affected by chronic ozone stress. Journal of Plant Diseases and Protection 98, 513-525.

Pleijel, H., Skärby, L., Ojanperä, K., Selldén, G., 1992. Yield and quality of spring barley, Hordeum vulgare L., exposed to different concentrations of ozone in opentop chambers. Agriculture, Ecosystems and Environment 38, 21-29.

Temple, P.J., Taylor, O.C., Benoit, L.F., 1985. Effects of ozone on yield of two fieldgrown barley cultivars. Environmental Pollution (Series A) 39, 217-225.

Wahid, A., 2006. Productivity losses in barley attributable to ambient atmospheric pollutants in Pakistan. Atmospheric Environment 40, 5342-5354.

Bean

Adaros, G., Weigel, H.J., Jäger, H.-J., 1990. Effects of incremental ozone concentrations on the yield of bush beans (Phaseolus vulgaris var. nanus [L.] Aschers) Gartenbauwissenschaft 55, 162-171.

Bender, J., Weigel, H.J., Jäger, H.-J., 1991. Response of nitrogen metabolism in beans (Phaseolus vulgaris L.) after exposure to ozone and nitrogen dioxide, alone and in sequence. New Phytologist 119, 261-267.

Brunschön-Harti, S., Fangmeier, A., Jäger, H.-J., 1995. Influence of ozone and ethylenediurea (EDU) on growth and yield of bean (Phaseolus vulgaris L.) in open-top field chambers. Environmental Pollution 90, 89-94.

Flowers, M.D., Fiscus, E.L., Burkey, K.O., Booker, F.L., Dubois, J.B., 2007. Photosynthesis, chlorophyll fluorescence, and yield of snap bean (Phaseolus vulgaris L.) genotypes differing in sensitivity to ozone. Environmental and Experimental Botany 61, 190-198.

Heck, W.W., Dunning, J.A., Reinert, R.A., Prior, S.A., 1988. Differential responses of four bean cultivars to chronic doses of ozone. Journal of American Society of Horticultural Science 113, 46-51.

Kohut, R., Laurence, J.A., 1983. Yield response of red kidney bean Phaseolus vulgaris to incremental ozone concentrations in the field. Environmental Pollution (Series A) 32, 233-240.

Kohut, R.J., Laurence, J.A., Colavito, L.J., 1988. The influence of ozone exposure dynamics on the growth and yield of kidney bean. Environmental Pollution 53 $79-88$

Miller, J.E., Pursley, W.A., Heagle, A.S., 1994. Effects of ethylenediurea on snap bean at a range of ozone concentrations. Journal of Environmental Quality 23 1082-1089.

Mohamed, A.I., Bhardwaj, H.L., Rangappa, M., Hoggard, G., 1995. Seed characteristics and nutrient composition of selected beans (Phaseolus vulgaris L.) with different ozone tolerance. Plant Foods for Human Nutrition 47, 29-38.

Sanders, G.E., Colls, J.J., Clark, A.G., 1992. Physiological changes in Phaseolus vulgaris in response to long-term ozone exposure. Annals of Botany 69,123-133. Sanders, G.E., Colls, J.J., Clark, A.G., Galaup, S., Bonte, J., Cantuel, J., 1992. Phaseolus vulgaris and ozone: results from open-top chamber experiments in France and England. Agriculture, Ecosystems and Environment 38, 31-40.

Sanders, G.E., Robinson, A.D., Geissler, P.A., Colls, J.J., 1992. Yield stimulation of a commonly grown cultivar of Phaseolus vulgaris at near-ambient ozone concentrations. New Phytologist 122, 63-70.

Schenone, G., Botteschi, G., Fumagalli, I., Montinaro, F., 1992. Effects of ambient air pollution in open-top chambers on bean (Phaseolus vulgaris L.) I. Effects on growth and yield. New Phytologist 122, 689-697.

Temple, P.J., 1991. Variations in responses of dry bean (Phaseolus vulgaris) cultivars to ozone. Agriculture, Ecosystems and Environment 36,1-11.

Tonneijck, A.E.G., van Dijk, C.J., 1998. Responses of bean (Phaseolus vulgaris L. cv. Pros) to chronic ozone exposure at two levels of atmospheric ammonia. Environmental Pollution 99, 45-51.

Craigon, J., Fangmeier, A., Jones, M., Donnelly, A., Bindi, M., De Temmerman, L., Persson, K., Ojanpera, K., 2002. Growth and marketable-yield responses of potato to increased $\mathrm{CO}_{2}$ and ozone. European Journal of Agronomy 17, 273-289. Donnelly, A., Craigon, J., Black, C.R., Colls, J.J., Landon, G., 2001. Elevated $\mathrm{CO}_{2}$ increases biomass and tuber yield in potato even at high ozone concentrations. New Phytologist 149, 265-274.

Fangmeier, A., De Temmerman, L, Black, C, Persson, K, Vorne, V , 2002. Effects of elevated $\mathrm{CO}_{2}$ and/or ozone on nutrient concentrations and nutrient uptake of potatoes. European Journal of Agronomy 17, 353-368.

Heagle, A.S., Miller, J.E., Pursley, W.A., 2003. Growth and yield responses of potato to mixtures of carbon dioxide and ozone. Journal of Environmental Quality 32, 1603-1610.

Köllner, B., Krause, G.H.M., 2000. Changes in carbohydrates, leaf pigments and yield in potatoes induced by different ozone exposure regimes. Agriculture, Ecosystems and Environment 78, 149-158.

Lawson, T., Craigon, J., Black, C.R., Colls, J.J., Tulloch, A.M., Landon, G., 2001. Effects of elevated carbon dioxide and ozone on the growth and yield of potatoes (Solanum tuberosum) grown in open-top chambers. Environmental Pollution 111, 479-491.

Pell, E.J., Pearson, N.S., Vinten-Johansen, C., 1988. Qualitative and quantitative effects of ozone and/or sulfur dioxide on field-grown potato plants. Environmental Pollution 53,171-186.

Persson, K., Danielsson, H., Selldén, G., Pleijel, H., 2003. The effects of tropospheric ozone and elevated carbon dioxide on potato (Solanum tuberosum L. cv. Bintje) growth and yield. The Science of the Total Environment 310, 191-201. Piikki, K., Selldén, G., Pleijel, H., 2004. The impact of tropospheric $\mathrm{O}_{3}$ on leaf number duration and tuber yield of the potato (Solanum tuberosum L.) cultivars Bintje and Kardal. Agriculture, Ecosystems and Environment 104, 483-492.

Rice

Feng, Z.W., Jin, M.H., Zhang, F.Z., Huang, Y.Z., 2003. Effects of ground-level ozone $\left(\mathrm{O}_{3}\right)$ pollution on the yields of rice and winter wheat in the Yangtze River Delta. Journal of Environmental Sciences (China) 15, 360-362.

Ishii, S., Marshall, F.M., Bell, J.N.B., Abdullah, A.M., 2004. Impact of ambient air pollution on locally grown rice cultivars (Oryza sativa L.) in Malaysia. Water, Air and Soil Pollution 154, 187-201.

Kats, G., Dawson, P.J., Bytnerowicz, A., Wolf, J.W., Thompson, C.R., Olszyk, D.M., 1985. Effects of ozone or sulfur-dioxide on growth and yield of rice. Agriculture, Ecosystems and Environment 14, 103-117.

Kobayashi, K., Okada, M., Nouchi, I., 1995. Effects of ozone on dry-matter partitioning and yield of Japanese cultivars of rice (Oryza sativa L). Agriculture, Ecosystems and Environment 53, 109-122.

Maggs, R., Ashmore, M.R., 1998. Growth and yield responses of Pakistan rice (Oryza sativa L.) cultivars to $\mathrm{O}_{3}$ and $\mathrm{NO}_{2}$. Environmental Pollution 103, 159-170. Maggs, R., Wahid, A., Shamsi, S.R.A., Ashmore, M.R., 1995. Effects of ambient air pollution on wheat and rice yield in Pakistan. Water, Air and Soil Pollution 85, 1311-1316. 
Wheat

Adaros, G., Weigel, H.J., Jäger, H.-J., 1991. Concurrent exposure to $\mathrm{SO}_{2}$ and/or $\mathrm{NO}_{2}$ alters growth and yield responses of wheat and barley to low concentrations of $\mathrm{O}_{3}$. New Phytologist 118, 581-591.

Adaros, G., Weigel, H.J., Jäger, H.-J., 1991. Impact of ozone on growth and yield parameters of two spring wheat cultivars (Triticum aestivum L.). Journal of Plant Diseases and Protection 98, 113-124.

Bender, J., Weigel, H.J., Wegner, U., Jäger, H.-J., 1994. Response of cellular antioxidants to ozone in wheat flag leaves at different stages of plant development. Environmental Pollution 84, 15-21.

De Temmerman, L., Vandermeiren, K., Guns, M., 1992. Effects of air filtration on spring wheat grown in open-top field chambers at a rural site. I. Effect on growth, yield and dry matter partitioning. Environmental Pollution 77, 1-5.

Fangmeier, A., Brockerhoff, U., Grüters, U., Jäger, H.-J., 1994. Growth and yield responses of spring wheat (Triticum aestivum L. cv. Turbo) grown in open-top chambers to ozone and water stress. Environmental Pollution 83, 317-325.

Feng, Z.W., Jin, M.H., Zhang, F.Z., Huang, Y.Z., 2003. Effects of ground-level ozone $\left(\mathrm{O}_{3}\right)$ pollution on the yields of rice and winter wheat in the Yangtze River Delta. Journal of Environmental Sciences (China) 15, 360-362.

Feng, Z.Z., Yao, F.F., Chen, Z., Wang, X.K., Zheng, Q.W., Feng, Z.W., 2007. Response of gas exchange and yield components of field-grown Triticum aestivum L. to elevated ozone in China. Photosynthetica 45, 441-446.

Finnan, J.M., Jones, M.B., Burke, J.I., 1996. A time-concentration study on the effects of ozone on spring wheat (Triticum aestivum L.). 1. Effects on yield. Agriculture, Ecosystems and Environment 57, 159-167.

Fuhrer, J., Egger, A., Lehnherr, B., Grandjean, A., Tschannen, W., 1989. Effects of ozone on the yield of spring wheat (Triticum aestivum L., cv. Albis) grown in open-top field chambers. Environmental Pollution 60, 273-289.

Fuhrer, J., Grimm, G.A., Tschannen, W., Shariat-Madari, H., 1992. The response of spring wheat (Triticum aestivum L.) to ozone at higher elevations II. Changes in yield, yield components and grain quality in response to ozone flux. New Phytologist 121, 211-219.

Gelang, J., Pleijel, H., Sild, E., Danielsson, H., Younis, S., Selldén, G., 2000. Rate and duration of grain filling in relation to flag leaf senescence and grain yield in spring wheat (Triticum aestivum L.) exposed to different concentrations of ozone. Physiologia Plantarum 110, 366-375.

Gelang, J., Selldén, G., Younis, S., Pleijel, H., 2001. Effects of ozone on biomass, non-structural carbohydrates and nitrogen in spring wheat with artificially manipulated source/sink ratio. Environmental and Experimental Botany 46, 155-169.

Heagle, A.S., Miller, J.E., Pursley, W.A., 2000. Growth and yield responses of winter wheat to mixtures of ozone and carbon dioxide. Crop Science 40, 16561664.

Kress, L.W., Miller, J.E., Smith, H.J., 1985. Impact of ozone on winter wheat yield. Environmental and Experimental Botany 25, 211-228.

Lehnherr, B., Grandjean, A., Machler, F., Fuhrer, J., 1987. The effect of ozone in ambient air on rubulosebisphosphate carboxylase/oxygenase activity decreases photosynthesis and grain yield in wheat. Journal of Plant Physiology 130, 189-200.

Mckee, I.F., Bullimore, J.F., Long, S.P., 1997. Will elevated $\mathrm{CO}_{2}$ concentrations protect the yield of wheat from $\mathrm{O}_{3}$ damage? Plant Cell and Environment 20, 77-84. McKee, I.F., Long, S.P., 2001. Plant growth regulators control ozone damage to wheat yield. New Phytologist 152, 41-51.

Mortensen, L., Engvild, K.C., 1995. Effects of ozone on ${ }^{14} \mathrm{C}$ translocation velocity and growth of spring wheat (Triticum aestivum L.) exposed in open-top chambers. Environmental Pollution 87, 135-140.

Mulholland, B.J., Craigon, J., Black, C.R., Colls, J.J., Atherton, J., Landon, G., 1996. Effects of elevated carbon dioxide and ozone on the growth and yield of spring wheat (Triticum aestivum L.). Journal of Experimental Botany 48, 113-122.

Nussbaum, S., Geissmann, M., Fuhrer, J., 1995. Effect of nitric oxide and ozone on spring wheat (Triticum aestivum L.). Water, Air and Soil Pollution 85, 1449-1454. Ojanperä, K., Patsikka, E., Ylaranta, T., 1998. Effects of low ozone exposure of spring wheat on net $\mathrm{CO}_{2}$ uptake, Rubisco, leaf senescence and grain filling. New Phytologist 138, 451-460.

Olszyk, D.M., Bytnerowicz, A., Kats, G., Dawson, P.J., Wolf, J., Thompson, C.R., 1986. Effects of sulfur dioxide and ambient ozone on winter wheat and lettuce. Journal of Environmental Quality 15, 363-369.

Pleijel, H., Danielsson, H., Gelang, J., Sild, E., Selldén, G., 1998. Growth stage dependence of the grain yield response to ozone in spring wheat (Triticum aestivum L.). Agriculture, Ecosystems and Environment 70, 61-68.

Pleijel, H., Skärby, L., Wallin, G., Selldén, G., 1991. Yield and grain quality of spring wheat (Triticum aestivum L., cv. Drabant) exposed to different concentrations of ozone in open-top chambers. Environmental Pollution 69, 151-168.

Rudorff, B.F.T., Mulchi, C.L., Lee, E.H., Rowland, R., Pausch, R., 1996. Effects of enhanced $\mathrm{O}_{3}$ and $\mathrm{CO}_{2}$ enrichment on plant characteristics in wheat and corn. Environmental Pollution 94, 53-60.

Tiedemann, A.V., Firsching, K.H., 2000. Interactive effects of elevated ozone and carbon dioxide on growth and yield of leaf rust-infected versus non-infected wheat. Environmental Pollution 108, 357-363.

Wahid, A., 2006. Influence of atmospheric pollutants on agriculture in developing countries: a case study with three new wheat varieties in Pakistan. Science of the Total Environment 371, 304-313.

Wahid, A., Maggs, R., Shamsi, S.R.A., Bell, J.N.B., Ashmore, M.R., 1995. Air pollution and its impacts on wheat yield in the Pakistan Punjab. Environmental Pollution 88, 147-154.

\section{References}

Adams, D.C., Gurevitch, J., Rosenberg, M.S., 1997. Resampling tests for meta-analysis of ecological data. Ecology 78, 1277-1283.

Ainsworth, E.A., 2008. Rice production in a changing climate: a meta-analysis of responses to elevated carbon dioxide and elevated ozone concentration. Global Change Biology 14, 1642-1650.

Ainsworth, E.A., Davey, P.A., Bernacchi, C.J., Dermody, O.C., Heaton, E.A., Moore, D.J., Morgan, P.B., Naidu, S.L., Yoora, H.S., Zhu, X.G., Curtis, P., Long, S.P., 2002. A meta-analysis of elevated $\left[\mathrm{CO}_{2}\right]$ effects on soybean (Glycine max) physiology, growth and yield. Global Change Biology 8, 695-709.

Andersen, C.P., 2003. Source-sink balance and carbon allocation below ground in plants exposed to ozone. New Phytologist 157, 213-228.

Ashmore, M.R., 2002. Effects of oxidants at the whole plant and community level. In: Treshow, M. (Ed.), Air Pollution and Plants. John Wiley, London, UK, pp. $89-118$.

Ashmore, M.R., 2005. Assessing the future global impacts of ozone on vegetation. Plant, Cell and Environment 28, 949-964

Ashmore, M., Toet, S., Emberson, L., 2006. Ozone - a significant threat to future world food production? New Phytologist 170, 201-204.

Benton, J., Fuhrer, J., Gimeno, B.S., Skärby, L., Palmer-Brown, D., Ball, G. Roadknight, C., Mills, G., 2000. An international cooperative programme indicates the widespread occurrence of ozone injury on crops. Agriculture, Ecosystems and Environment 78, 19-30.

Biswas, D.K., Xu, H., Li, Y.G., Sun, J.Z., Wang, X.Z., Han, X.G., Jiang, G.M., 2008 Genotypic differences in leaf biochemical, physiological and growth responses to ozone in 20 winter wheat cultivars released over the past 60 years. Global Change Biology 14, 46-59.

Black, V.J., Black, C.R., Roberts, J.A., Stewart, C.A., 2000. Impact of ozone on the reproductive development of plants. New Phytologist 147, 421-447.

Booker, F., Fiscus, E.L., 2005. The role of ozone flux and antioxidants in the suppression of ozone injury by elevated $\mathrm{CO}_{2}$ in soybean. Journal of Experimental Botany 56, 2139-2151.

Cardoso-Vilhena, J., Balaguer, L., Eamus, D., Ollerenshaw, J., Barnes, J., 2004. Mechanisms underlying the amelioration of $\mathrm{O}_{3}$-induced damage by elevated atmospheric concentrations of $\mathrm{CO}_{2}$. Journal of Experimental Botany 55, 771-781.

Clarke, B.B., Greenhalgh-Weidman, B., Brennan, E.G., 1990. An assessment of the impact of ambient ozone on field-grown crops in New Jersey using the EDU method: part 1 white potato (Solanum tuberosum). Environmental Pollution 66, 351-360.

Coats, B., 2003. Global rice production. In: Smith, C.W., Dilday, R.H. (Eds.), Rice Origin, History, Technology and Production. John Wiley \& Sons, Inc., Hoboken New Jersey, USA, pp. 247-470.

Curtis, P.S., Wang, X., 1998. A meta-analysis of elevated $\mathrm{CO}_{2}$ effects on woody plant mass, form, and physiology. Oecologia 113, 299-313.

De Temmerman, L., Hacour, A., Guns, M., 2002. Changing climate and potential impacts on potato yield and quality 'CHIP': introduction, aims and methodology. European Journal of Agronomy 17, 233-242.

Dixon, J., Hull, M.R., Cobb, A.H., Sanders, G.E., 1995. Ozone pollution modifies the response of sugarbeet to the herbicide phenmedipham. Water, Air and Soil Pollution 85, 1443-1448.

Feng, Z.Z., Kobayashi, K., Ainsworth, E.A., 2008. Impact of elevated ozone concentration on growth, physiology and yield of wheat (Triticum aestivum L.): a metaanalysis. Global Change Biology 14, 2696-2708.

Feng, Z.Z., Wang, X.K., Zheng, Q.W., Feng, Z.W., Xie, J.Q., Chen, Z., 2006. Response of gas exchange of rape to ozone concentration and exposure regimes. Acta Ecologica Sinica 26, 823-829.

Feng, Z.Z., Yao, F.F., Chen, Z., Wang, X.K., Zheng, Q.W., Feng, Z.W., 2007. Response of gas exchange and yield components of field-grown Triticum aestivum L. to elevated ozone in China. Photosynthetica 45, 441-446.

Feng, Z.W., Jin, M.H., Zhang, F.Z., Huang, Y.Z., 2003. Effects of ground-level ozone $\left(\mathrm{O}_{3}\right)$ pollution on the yields of rice and winter wheat in the Yangtze River Delta. Journal of Environmental Science (China) 15, 360-362.

Fincher, J., Cumming, J.R., Alscher, R.G., Rubin, G., Weinstein, L., 1989. Long-term ozone exposure affects winter hardiness of red spruce (Picea rubens Sarg.) seedlings. New Phytologist 113, 85-96.

Fiscus, E.L., Booker, F.L., Burkey, K.O., 2005. Crop responses to ozone: uptake, modes of action, carbon assimilation and partitioning. Plant, Cell and Environment 28 997-1011.

Fuhrer, J., Booker, F., 2003. Ecological issues related to ozone: agricultural issues Environment International 29, 141-154

Fuhrer, J., Skärby, L., Ashmore, M.R., 1997. Critical levels for ozone effects on vegetation in Europe. Environmental Pollution 97, 91-106.

Gilland, B., 2002. Can food production keep pace with population growth in the next half-century? Food Policy 27, 47-63.

Grantz, D.A., Gunn, S., Vu, H.B., 2006. $\mathrm{O}_{3}$ impacts on plant development: a metaanalysis of root/shoot allocation and growth. Plant, Cell and Environment 29 1193-1209.

Gregory, P.J., Ingram, J.S.I., 2000. Global change and food and forest production: future scientific challenges. Agriculture, Ecosystems and Environment 82, 3-14.

Heagle, A.S., 1989. Ozone and crop yield. Annual Review of Phytopathology 27, 397423.

Heck, W.W., Dunning, J.A., Reinert, R.A., Prior, S.A., 1988. Differential responses of four bean cultivars to chronic doses of ozone. Journal of American Society of Horticultural Science 113, 46-51.

Hedges, L.V., Gurevitch, J., Curtis, P.S., 1999. The meta-analysis of response ratios in experimental ecology. Ecology 80, 1150-1156. 
Jäger, H.-J., Unsworth, M., De Temmerman, L., Mathy P., 1992. Effects of air pollution on agricultural crops in Europe, results of the European open-top chambers project. In: Air Pollution Research Report 46, Belgium.

Karnosky, D., Skelly, J., Percy, K., Chappelka, A., 2007. Prospectives regarding 50 years of research on effects of tropospheric ozone air pollution on US forests. Environmental Pollution 147, 489-506.

Kobayashi, K., 1992. Modeling and assessing the impact of ozone on rice growth and yield. In: Berglund, R.L. (Ed.), Tropospheric Ozone and the Environment II. Air and Waste Management Association, Pittsburgh, USA, pp. 537-551.

Kobayashi, K., Okada, M., Nouchi, I., 1995. Effects of ozone on dry matter partitioning and yield of Japanese cultivars of rice (Oryza sativa L.). Agriculture, Ecosystems and Environment 53, 109-122.

Krupa, S., McGrath, M.T., Andersen, C.P., Booker, F.L., Burkey, K.O., Chappelka, A.H., Chevone, B.I., Pell, E.J., Zilinskas, B.A., 2001. Ambient ozone and plant health. Plant Disease 85, 4-12.

Lesser, V.M., Rawlings, J.O., Spruill, S.E., Somerville, M.C., 1990. Ozone effects on agricultural crops - statistical methodologies and estimated dose-response relationships. Crop Science 30, 148-155.

Long, S.P., Naidu, S.L., 2002. Effects of oxidants at the biochemical, cell and physiological levels. In: Treshow, M. (Ed.), Air Pollution and Plants. John Wiley, London, UK, pp. 69-88.

Maggs, R., Ashmore, M.R., 1998. Growth and yield responses of Pakistan rice (Oryza sativa L.) cultivars to $\mathrm{O}_{3}$ and $\mathrm{NO}_{2}$. Environmental Pollution 103, 159-170.

Maggs, R., Wahid, A., Shamsi, S.R.A., Ashmore, M.R., 1995. Effects of ambient air pollution on wheat and rice yield in Pakistan. Water, Air and Soil Pollution 85, 1311-1316.

McLeod, A.R., Long, S.P., 1999. Free-air carbon dioxide enrichment (FACE) in globa change research: a review. Advances in Ecological Research 28, 1-55.

Meehl, G.A., Stocker, T.F., Collins, W.D., Friedlingstein, P., Gaye, A.T., Gregory, J.M., Kitoh, A., Knutti, R., Murphy, J.M., Noda, A., Raper, S.C.B., Watterson, I.G., Weaver, A.J., Zhao, Z.C., 2007. Global climate projections. In: Solomon, S., Qin, D., Manning, M., Chen, Z., Marquis, M., Averyt, K.B., Tignor, M., Miller, H.L. (Eds.), Climate Change 2007: The Physical Science Basis. Contribution of Working Group I to the Fourth Assessment Report of the Intergovernmental Panel on Climate Change. Cambridge University Press, Cambridge, United Kingdom and New York, NY, USA.

Mills, G., Buse, A., Gimeno, B., Bermejo, V., Holland, M., Emberson, L., Pleijel, H., 2007. synthesis of AOT40-based response functions and critical levels of ozone for agricultural and horticultural crops. Atmospheric Environment 41, 2630-2643.

Mills, G., Hayes, F., Buse, A., Reynolds, B., 2000. Air pollution and vegetation. In: Annual Report 1999/2000 of UN/ECE ICP Vegetation. Centre for Ecology and Hydrology, Bangor, UK

Morgan, P.B., Ainsworth, E.A., Long, S.P., 2003. How does elevated ozone impact soybean? A meta-analysis of photosynthesis, growth and yield. Plant, Cell and Environment 26, 1317-1328.

Morgan, P.B., Mies, T.A., Bollero, G.A., Nelson, R.L., Long, S.P., 2006. Season-long elevation of ozone concentration to projected 2050 levels under fully open-air conditions substantially decreases the growth and production of soybean. New Phytologist 170, 333-343.

Murphy, J., Delucchi, M.A., McCubbin, D.R., Kim, H.J., 1999. The cost of crop damage caused by ozone air pollution from motor vehicles. Journal of Environmenta Management 55, 273-289.

Nouchi, I., Ito, O., Harazono, Y., Kouchi, H., 1995. Acceleration of ${ }^{13}$ C-labelled photosynthate partitioning from leaves to panicles in rice plants exposed to chronic ozone at the reproductive stage. Environmental Pollution 88, 253-260.
Nussbaum, S., Fuhrer, J., 2000. Difference in ozone uptake in grassland species between open-top chambers and ambient air. Environmental Pollution 109, 463-471.

Piikki, K., De Temmerman, L., Högy, P., Pleijel, H., 2008. The open-top chamber impact on vapour pressure deficit and its consequences for stomatal ozone uptake. Atmospheric Environment 42, 6513-6522.

Pleijel, H., Danielsson, H., Emberson, L., Ashmore, M.R., Mills, G., 2007. Ozone risk assessment for agricultural crops in Europe: further development of stomatal flux and flux-response relationships for European wheat and potato. Atmospheric Environment 41, 3022-3040.

Pleijel, H., Danielsson, H., Ojanperä, K., De Temmerman, L., Högy, P., Badiani, M., Karlsson, P.E., 2004. Relationships between ozone exposure and yield loss in European wheat and potato - a comparison of concentration- and flux-based exposure indices. Atmospheric Environment 38, 2259-2269.

Rosenberg, M.S., Adams, D.C., Gurevitch, J., 2000. Metawin: Statistical Software for Meta-Analysis, Version 2.1. Sinauer Associates, Inc, Sunderland, MA, USA.

Schenone, G., Botteschi, G., Fumagalli, I., Montinandi, F., 1992. Effects of ambient air pollution in open top chambers on bean (Phaseolus vulgaris L): effects on growth and yield. New Phytologist 122, 689-697.

Taub, D.R., Miller, B., Allen, H., 2008. Effects of elevated $\mathrm{CO}_{2}$ on the protein concentration of food crops: a meta-analysis. Global Change Biology 14, 565-575.

United States Bureau of the Census database (USBC), 2001. Available from: <www. census.gov>.

Vandermeiren, K., Black, C., Pleijel, H., De Temmerman, L., 2005. Impact of rising tropospheric ozone on potato: effects on photosynthesis, growth, productivity and yield quality. Plant, Cell and Environment 28, 982-996.

Vingarzan, R., 2004. A review of surface ozone background levels and trends. Atmospheric Environment 38, 3431-3442.

Volz, A., Kley, D., 1988. Evaluation of the montsouris series of ozone measurements made in the 19th-century. Nature 332, 240-242.

Wahid, A., Maggs, R., Shamsi, S.R.A., Bell, J.N.B., Ashmore, M.R., 1995. Air pollution and its impacts on wheat yield in the Pakistan Punjab. Environmental Pollution $88,147-154$

Wang, H.X., Zhou, L.J., Tang, X.Y., 2006. Ozone concentrations in rural regions of the Yangtze Delta in China. Journal of Atmospheric Chemistry 54, 255-265.

Wang, X., Mauzerall, D.L., 2004. Characterising distributions of surface ozone and its impacts on grain production in China, Japan and South Korea. Atmospheric Environment 38, 4383-4402.

Wang, X.K., Manning, W.J., Feng, Z.W., Zhu, Y.G., 2007a. Ground-level ozone in China: distribution and effects on crop yields. Environmental Pollution 147, 394-400.

Wang, X.K., Zheng, Q.W., Yao, F.F., Chen, Z., Feng, Z.Z., Manning, W.J., 2007b. Assessing the impact of ambient ozone on growth and yield of a rice (Oryza sativa L.) and a wheat (Triticum aestivum L.) cultivar grown in the Yangtze Delta, China, using three rates of application of ethylenediurea (EDU). Environmental Pollution 148, 390-395.

Wolf, J., Van Oijen, M., 2003. Model simulation of effects of changes in climate and atmospheric $\mathrm{CO}_{2}$ and $\mathrm{O}_{3}$ on tuber yield potential of potato (cv. Bintje) in the European Union. Agriculture, Ecosystems and Environment 94, $141-157$.

Yamaji, K, Ohara, T, Uno, I, Kurokawa, J, Pochanart, P., Akimoto, H. 2008 Future prediction of surface ozone over east Asia using models-3 community multiscale air quality modeling system and regional emission inventory in Asia. Journal of Geophysical Research 113, D08306. doi:10.1029/ 2007JD008663. 